\title{
Compilation of radiogenic isotope data in Mexico and their petrogenetic implications
}

\author{
Ignacio S Torres-Alvarado ${ }^{1}$, Surendra P Verma ${ }^{1}$ and Gerardo Carrasco-Núñez ${ }^{2}$ \\ ${ }^{1}$ Centro de Investigación en Energía, UNAM, Priv. Xochicalco s/n, Col. Centro, Apdo. Postal 34, 62580 \\ Temixco, Morelos, Mexico. \\ email: ita@mazatl.cie.unam.mx \\ ${ }^{2}$ Instituto de Geología, UNAM, Circuito Exterior, Cd. Universitaria, 04510 Mexico, D.F., Mexico.
}

\begin{abstract}
Seven hundred and twenty-five Sr, two hundred and forty-three $\mathrm{Nd}$ and one hundred and fifty-one $\mathrm{Pb}$ isotopic ratios from seven different Mexican magmatic provinces were compiled in an extensive geochemical database. Data were arranged according to the Mexican geological provinces, indicating for each province total number of analyses, range and mean of values and two times standard deviation $(2 \sigma)$. Data from seven provinces were included in the database: Mexican Volcanic Belt (MVB), Sierra Madre Occidental (SMO), Baja California (BC), Pacific Ocean (PacOc), Altiplano (AP), Sierra Madre del Sur (SMS), and Sierra Madre Oriental (SMOr). Isotopic values from upper mantle and lower crustal xenoliths, basement outcrops and sediments from the Cocos Plate were also compiled. In the MVB the isotopic ratios range as follows: ${ }^{87} \mathrm{Sr} /{ }^{86} \mathrm{Sr} \quad 0.703003-0.70841 ;{ }^{143} \mathrm{Nd} /{ }^{144} \mathrm{Nd} \quad 0.512496-0.513098 ;{ }^{206} \mathrm{~Pb} /{ }^{204} \mathrm{~Pb} \quad 18.567-19.580$; ${ }^{207} \mathrm{~Pb} /{ }^{204} \mathrm{~Pb} 15.466-15.647 ;{ }^{208} \mathrm{~Pb} /{ }^{204} \mathrm{~Pb} 38.065-38.632$. The SMO shows a large variation in ${ }^{87} \mathrm{Sr} /{ }^{86} \mathrm{Sr}$ ranging from $\sim 0.7033$ to $0.71387 .{ }^{143} \mathrm{Nd} /{ }^{144} \mathrm{Nd}$ ratios are relatively less variable with values from 0.51191 to 0.51286 . Pb isotope ratios in the SMO are as follows: ${ }^{206} \mathrm{~Pb} /{ }^{204} \mathrm{~Pb} 18.060-18.860 ;{ }^{207} \mathrm{~Pb} /{ }^{204} \mathrm{~Pb} 15.558-$ $15.636 ;{ }^{208} \mathrm{~Pb} /{ }^{204} \mathrm{~Pb}$ 37.945-38.625. PacOc rocks show the most depleted $\mathrm{Sr}$ and Nd isotopic ratios (0.70232-0.70567 for Sr and 0.512631-0.513261 for Nd). Pb isotopes for PacOc show the following range: ${ }^{206} \mathrm{~Pb} /{ }^{204} \mathrm{~Pb} 18.049-19.910 ;{ }^{207} \mathrm{~Pb} /{ }^{204} \mathrm{~Pb} 15.425-15.734 ;{ }^{208} \mathrm{~Pb} /{ }^{204} \mathrm{~Pb} 37.449-39.404$. The isotopic ratios of the AP rocks seem to be within the range of those from the PacOc.

Most samples with reported Sr and Nd isotopic data are spread within and around the "mantle array". The SMO seems to have been formed by a mixing process between mantle derived magmas and continental crust. The MVB appears to have a larger mantle component, with AFC as the dominant petrogenetic process for the evolved rocks. There is still a need for $\mathrm{Pb}$ isotopic data in all Mexican magmatic provinces and of Nd isotopes in BC, AP, SMS, and SMOr.
\end{abstract}

\section{Introduction}

During the past three decades radiogenic isotopes have been developed into a powerful tool helping to identify geological processes and geochemical sources. Isotope ratios in a magma are characteristic of the source region and remain constant during later simple fractional crystallisation processes. Furthermore, contamination processes and mixing between isotopically distinct sources can be recognised (Faure 1986; Rollinson 1993). Due to the availability of modern analytical techniques and facilities, the number of radiogenic isotope analyses has increased rapidly in Mexico. However, little work has been done to compile and interpret these data in a unifying form since Verma and Verma (1986). This paper presents the preliminary results of an extensive compilation of published and some unpublished $\mathrm{Sr}, \mathrm{Nd}$ and $\mathrm{Pb}$ isotopic data from Mexican magmatic provinces and points out their petrogenetic implications. For other isotopes no observations were compiled in this database because only a few data are available (Th

Keywords. Radiogenic isotopes; Sr, Nd, Pb; magmatic provinces; Mexico; Pacific Ocean; Cocos Plate. 


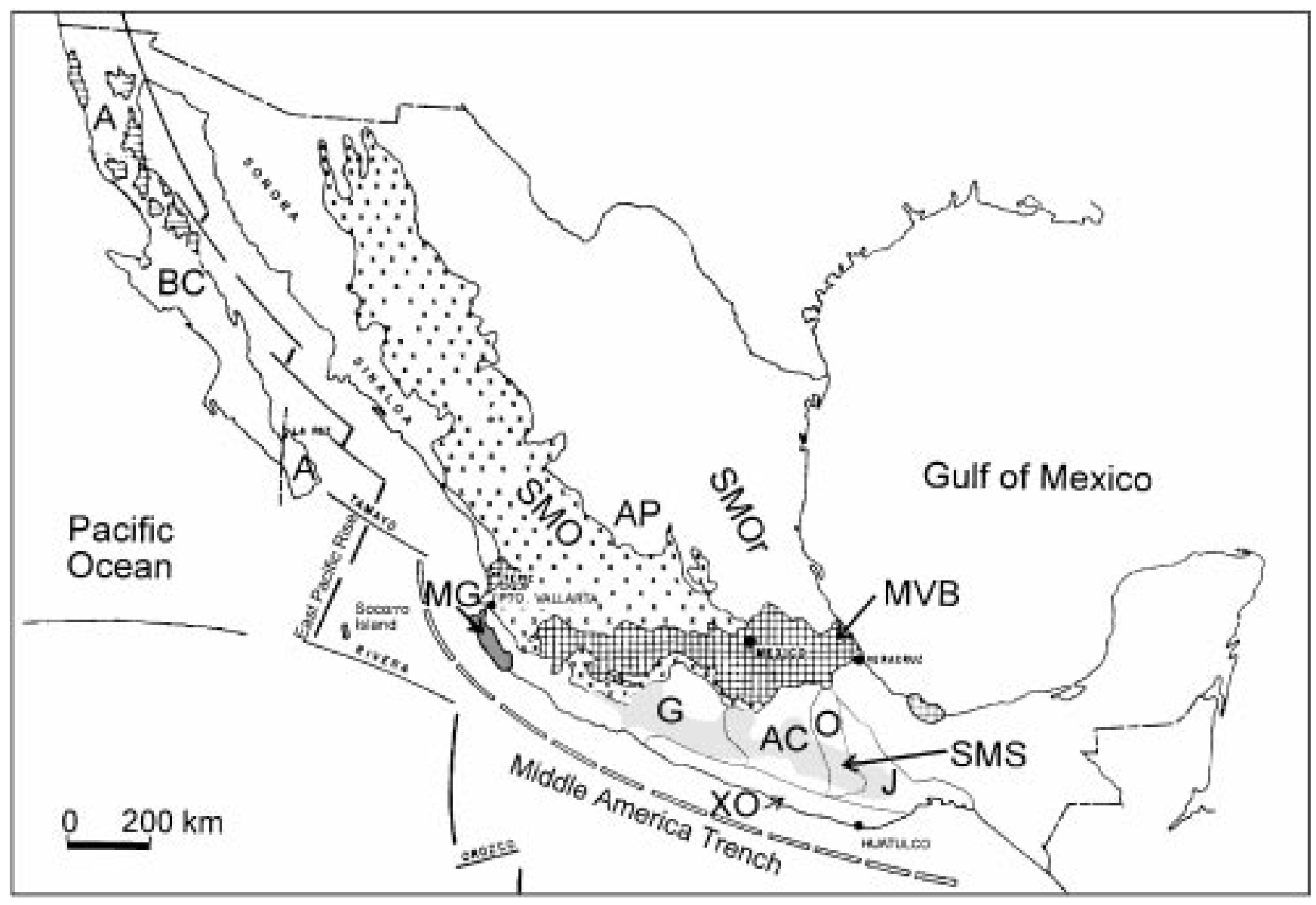

Figure 1. Principal magmatic provinces and tectono-stratigraphic terranes of Mexico. Abbreviations are MVB=Mexican Volcanic Belt; SMO=Sierra Madre Occidental; BC=Baja California; AP=Altiplano; SMS=Sierra Madre del Sur; $\mathbf{S M O r}=$ Sierra Madre Oriental. The SMS overlays the Guerrero terrane $(\mathbf{G})$, the Xolapa complex (XO), the Acatlan complex (AC), the Oaxaca complex (O), and the Juarez terrane (J; Campa and Coney 1983). A = Alisitos arc; MG = Mesozoic granites.

and U: Chen et al 1986; Hf: Salters 1996; Be: Tera et al 1986; He, Graham et al 1988; and O: Ferriz and Mahood 1987; Verma and Dobson 1987; Mahood and Halliday 1988).

\section{Geological setting}

Figure 1 shows the main magmatic provinces in Mexico. De Cserna (1989) has presented a summary of the geology of Mexico. Magmatic activity occurred relatively continuously since Jurassic times. The distribution, nature and structure of this magmatism are a response of important changes in the plate tectonic dynamics involving complex interactions among several plates: North American, Pacific, Cocos, Rivera, Caribbean and the extinct Farallon plate.

The Jurassic-Cretaceous volcanism occurred mainly among the Baja California Peninsula as part of a large island arc (Demant and Robin 1975) known as the Alisitos arc (Gastil et al 1971), when the ancient Farallon plate subducted under the North American plate, approximately parallel to the present coast line.
An extensive plutonism developed since the Cretaceous time from the northern states of Mexico (Baja California, Sonora and Sinaloa) to the Pacific coast in central Mexico, forming a large batholithic belt showing a relative migration towards the east. This resulted from changes in dip and velocity of the NNW-SSE trending Cretaceous-Tertiary subduction zone (Demant and Robin 1975; Molnar and Stock 1987; Atwater 1989; Lyle and Ness 1991; Delgado 1994).

The plutonic activity has been identified along the Pacific coast from Puerto Vallarta to Huatulco showing a systematic decrease in age eastward. This change in age has been attributed to a geometric artifact of oblique continental margin truncation (Schaaf et al 1995). The tectonic erosion associated with the subduction was the most important mechanism in the northwestern segment, and the lateral removal of material associated with the displacement of the Chortis block in the southeastern segment.

According to Herrman et al (1994) a plate reorganisation, originated from changes in rate, direction and dip of convergence between the Farallon and North 
American plates and the early evolution of the Caribbean, seems to have induced a shift of the magmatic arc from its Cretaceous and early Tertiary location (Sierra Madre Occidental, SMO) to its present mid-Mexican position of Mexican Volcanic Belt (MVB).

During the Oligocene and early Miocene, an intense episode of ignimbritic volcanism occurred in Northwest Mexico forming the SMO, which is oriented parallel to the coast. This is the largest felsic province in the world (Lanphere et al 1980). In contrast, the E$\mathrm{W}$ trending MVB crosses the central part of Mexico, includes active volcanism and is dominantly andesitic in composition (Aguilar-Y-Vargas and Verma 1987; Verma and Aguilar-Y-Vargas 1988). The limits and relationship between these provinces, including the definition of the MVB has been a matter of discussion for many years. The onset of volcanism in the MVB is still under debate because of a lack of systematic geochronologic studies and a unified plate tectonic model for its origin. This initiation has been proposed in late Oligocene (Gunn and Mooser 1971; Mooser 1972), Miocene (Venegas S. et al 1985; Verma 1987), early Pliocene (Nixon et al 1987), Pliocene (Cantagrel and Robin 1979; Robin 1981), or Quaternary (Demant 1978, 1981). Ferrari et al (1994) proposed that the volcanism migration from the SMO to MVB occurred gradually in response to the development of the Middle American Trench (MAT) in early to middle Miocene times. They also pointed out that the overall orientation of the arc did not change since $16 \mathrm{Ma}$ to the Present, although a general trenchward migration of the volcanic front is observed, suggesting that the MVB proper began about that age.

Although many different models have been proposed to explain the origin of the MVB, such as those related to a week crustal zone associated with long strike-slip faults (Gastil and Jensky 1973), of a continental extension of the Clarion transform fault (Mooser and Maldonado 1961), or a gigantic "geosuture" between continental blocks (Mooser 1972), most authors believe that the MVB is a continental margin province that resulted from a subduction mechanism along the MAT (i.e. Molnar and Sykes 1969; Moorbath et al 1978; Demant 1981; Nixon 1982; Urrutia and Böhnel 1987). The lack of parallelism of the volcanic belt with the trench is explained by the variation in the subduction dip along the MAT (Pardo and Suárez 1995) and during different times. Alternative or more complex models are still not totally outdated (Shurbet and Cebull 1984; Cebull and Shurbet 1987; Verma 1994, 1999, 2000; Márquez et al 1999).

The MVB is a complex province composed of different zones (Demant 1978; Venegas S et al 1985; Pasquaré et al 1987; Aguilar-Y-Vargas and Verma 1987; Luhr 1997), whose characteristics have been attributed in part to different tectonic response of the basement rocks that underlay the MVB. These may include:

- Paleozoic and Mesozoic tectonostratigraphic terranes to the south (Ortega-Gutiérrez 1981; Campa and Coney 1983), which are affected by granitoid rocks and are covered by an important Tertiary volcanism that forms the Sierra Madre del Sur (SMS) province (Morán-Zenteno et al 1998).

- To the NW is the ignimbritic sequence of SMO.

- To the central and eastern parts there are thick sedimentary sequences of highly deformed Mesozoic rocks that build the Sierra Madre Oriental (SMOr).

The southern terranes of Mexico (Ortega-Gutiérrez 1981, 1983; Campa and Coney 1983; Carfantan 1986) that form the basement of the MVB and the SMS Tertiary provinces are (figure 1): the Guerrero terrane (G; Jurassic-Cretaceous), the Acatlán complex (AC; late Paleozoic and younger), the Oaxaca terrane (O; Grenvillian age), the Xolapa terrane (XO; PaleozoicTertiary) and the Juárez terrane (J; Mesozoic). It is not at present possible to clearly define the relationships between these terranes to unravel the structure of the basement rocks. However, Ortega-Gutiérrez (1983) proposed that different blocks of continental crust accreted around the Oaxaca complex during Paleozoic and Mesozoic times.

There are other regions in Mexico with minor but not less important volcanism. The high plains of Central Mexico, called as the Altiplano (AP) region, show a scattered alkaline volcanism that has been associated with the southern extension of the Basin and Range province. This Pliocene-Quaternary volcanism comprises several maar volcanoes, which produced abundant xenoliths from the mantle and the lower crust (Luhr et al 1995). Also, within the Mesozoic sedimentary province of the SMOr, numerous plutonic bodies were responsible for various ore deposits produced during the Tertiary. Finally, volcanic islands in the Pacific Ocean represent an isolated volcanism producing Ocean Island Basalts (Bohrson and Reid 1995), associated with a still active magmatic system.

\section{Methodology}

${ }^{87} \mathrm{Sr} /{ }^{86} \mathrm{Sr}, \quad{ }^{143} \mathrm{Nd} /{ }^{144} \mathrm{Nd}, \quad{ }^{206} \mathrm{~Pb} /{ }^{204} \mathrm{~Pb},{ }^{207} \mathrm{~Pb} /{ }^{204} \mathrm{~Pb}$, and ${ }^{208} \mathrm{~Pb} /{ }^{204} \mathrm{~Pb}$ ratios were compiled in one thousand one hundred and nineteen analyses of rock samples. Depending on the geological region, samples may include volcanic rocks of different composition, plutonic units, as well as some mineral separates. These data were extracted from forty-seven literature sources (some of them still unpublished or in press), which include most of the isotopic analyses performed to date in the major magmatic regions in Mexico. In order to save space, the complete compilation is not 


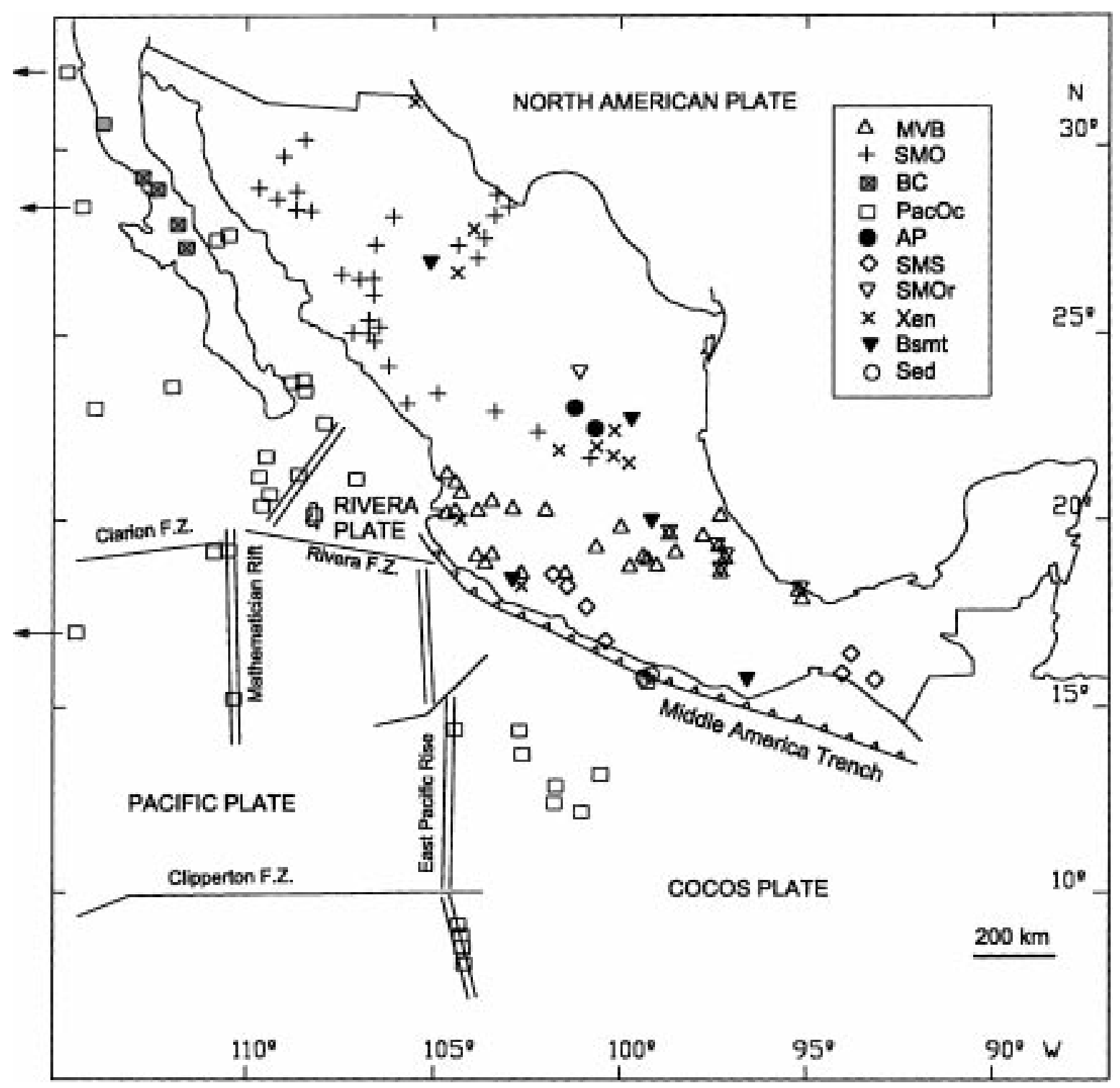

Figure 2. Sample locations from where $\mathrm{Sr}, \mathrm{Nd}$ and/or $\mathrm{Pb}$ data were compiled for this work. PacOc= Pacific Ocean; Xen = Xenolith; Bsmt = Basement outcrops; Sed = sediments; F.Z. = Fracture Zone. Other abbreviations are the same as in figure 1.

included in this paper, but a summary of the isotopic data organised in terms of geological provinces is presented here. Sample locations are shown schematically in figure 2. Only initial ${ }^{87} \mathrm{Sr} /{ }^{86} \mathrm{Sr}$ and ${ }^{143} \mathrm{Nd} /{ }^{144} \mathrm{Nd}$ values were included in the database, excepting those for xenoliths, basement outcrops and sediments, for which present isotopic values were compiled. Measured ${ }^{87} \mathrm{Sr} /{ }^{86} \mathrm{Sr}$ and ${ }^{143} \mathrm{Nd} /{ }^{144} \mathrm{Nd}$ were recalculated to their initial ratios in those cases when the ${ }^{87} \mathrm{Rb} /{ }^{86} \mathrm{Sr}$ and ${ }^{147} \mathrm{Sm} /{ }^{144} \mathrm{Nd}$ values, as well as the sample age, were available. Values of $1.42 \times 10^{-11} \mathrm{y}^{-1}$ (Steiger and Jäger 1977) and $6.54 \times 10^{-12} \mathrm{y}^{-1}$ (Lugmair and Marti 1978) were used as decay constants for $\mathrm{Rb}-\mathrm{Sr}$ and $\mathrm{Sm}-\mathrm{Nd}$ respectively. Finally, ${ }^{143} \mathrm{Nd} /{ }^{144} \mathrm{Nd}$ ratios were expressed in the epsilon notation $\left(\varepsilon_{\mathrm{Nd}}\right)$ for comparison between samples of different ages as suggested by DePaolo and Wasserburg (1976).

\section{Data analysis and discussion}

Table 1 presents the summary of the compiled data for ${ }^{87} \mathrm{Sr} /{ }^{86} \mathrm{Sr},{ }^{143} \mathrm{Nd} /{ }^{144} \mathrm{Nd},{ }^{206} \mathrm{~Pb} /{ }^{204} \mathrm{~Pb},{ }^{207} \mathrm{~Pb} /{ }^{204} \mathrm{~Pb}$, and ${ }^{208} \mathrm{~Pb} /{ }^{204} \mathrm{~Pb}$ values and organised into different magmatic provinces according to figure 1. Maximum and minimum values are shown for each province. Arithmetic mean and two standard deviation values $(2 \sigma)$ were also calculated. Important differences exist in the total number of available data for each isotopic ratio. For Sr isotopic values a total of seven hundred and twenty-five analyses was compiled, two hundred and forty-three values were reported for $\mathrm{Nd}$ and one hundred and fifty-one for $\mathrm{Pb}$ isotopes. Unfortunately all the five isotopic ratios were measured in only few samples. This fact presents serious limitations in the possible interpretation of geochemical data. 


\subsection{Mexican Volcanic Belt (MVB)}

Approximately $45 \%$ of the published Sr isotopic data have been reported for rocks sampled from the MVB. The ${ }^{87} \mathrm{Sr} /{ }^{86} \mathrm{Sr}$ values of these rocks range from
0.703003 to 0.70841 (arithmetic mean 0.70403). Volcanic rocks from this province show an increment in their $\mathrm{Sr}$ isotopic ratios with increasing $\mathrm{SiO}_{2}$ content. The histogram in figure 3(a) illustrates this trend, where basaltic rocks present the highest

Table 1. Sr, Nd and Pb isotope data of the main magmatic provinces in Mexico. Initial isotopic ratios are shown for all provinces, except for xenolith samples (Xen), basement outcrops (Bsmt) and sediments (Sed), for which the present values were compiled.

\begin{tabular}{|c|c|c|c|c|c|c|}
\hline \multicolumn{7}{|c|}{${ }^{87} \mathrm{Sr} /{ }^{86} \mathrm{Sr}$} \\
\hline Province & $n(725)$ & Min & $\operatorname{Max}$ & Mean & $2 \sigma$ & References \\
\hline MVB & 329 & 0.703003 & 0.70841 & 0.70403 & 0.00099 & $\begin{array}{l}7,10,11,12,13,14,17,18,19,20, \\
23,26,27,31,34,37,41,42,43,47\end{array}$ \\
\hline $\mathrm{SMO}$ & 105 & 0.7033 & 0.71387 & 0.7058 & 0.0034 & $1,2,3,5,6,9,21,36$ \\
\hline $\mathrm{BC}$ & 18 & 0.70311 & 0.70629 & 0.70404 & 0.00164 & $1,15,24$ \\
\hline $\mathrm{PacOc}$ & 123 & 0.70232 & 0.70567 & 0.703007 & 0.001249 & $16,22,32,33,38,47$ \\
\hline $\mathrm{AP}$ & 28 & 0.70286 & 0.70395 & 0.70318 & 0.00058 & 25,28 \\
\hline SMS & 22 & 0.70220 & 0.70670 & 0.70411 & 0.00256 & $4,5,30$ \\
\hline SMOr & 5 & 0.704 & 0.710 & 0.707 & 0.005 & 8 \\
\hline Xen & 57 & 0.702570 & 0.731853 & 0.706675 & 0.012118 & $31,34,44,45,46$ \\
\hline Bsmt & 21 & 0.703855 & 0.749957 & 0.712846 & 0.021334 & $31,34,44,45,46$ \\
\hline Sed & 17 & 0.707986 & 0.710340 & 0.708597 & 0.001157 & 47 \\
\hline \multicolumn{7}{|c|}{${ }^{143} \mathrm{Nd} /{ }^{144} \mathrm{Nd}$} \\
\hline & $n(243)$ & Min & $\operatorname{Max}$ & Mean & $2 \sigma$ & References \\
\hline MVB & 167 & 0.512396 & 0.513098 & 0.512819 & 0.000189 & $\begin{array}{l}11,12,17,18,19,20,23,27,31,37, \\
41,42,47\end{array}$ \\
\hline $\mathrm{SMO}$ & 25 & 0.51191 & 0.51286 & 0.51256 & 0.00038 & $1,3,21,36$ \\
\hline $\mathrm{BC}$ & 2 & 0.51263 & 0.51287 & 0.51275 & 0.00034 & 1 \\
\hline $\mathrm{PacOc}$ & 100 & 0.512631 & 0.513261 & 0.513044 & 0.000253 & $16,22,32,33,38,47$ \\
\hline $\mathrm{AP}$ & 28 & 0.51278 & 0.51301 & 0.51292 & 0.00011 & 25,28 \\
\hline Xen & 52 & 0.511920 & 0.513122 & 0.512615 & 0.000593 & $31,35,41,44,45,46$ \\
\hline Bsmt & 19 & 0.511833 & 0.512613 & 0.512145 & 0.000345 & 45,46 \\
\hline Sed & 17 & 0.512437 & 0.512556 & 0.512485 & 0.000075 & 47 \\
\hline \multicolumn{7}{|c|}{$\varepsilon_{\mathrm{Nd}}$} \\
\hline MVB & 167 & -2.77 & 8.97 & 3.40 & 3.67 & $\begin{array}{l}11,12,17,18,19,20,23,27,31,37, \\
41,42,47\end{array}$ \\
\hline SMO & 25 & -13.45 & 5.08 & -0.77 & 7.42 & $1,3,21,36$ \\
\hline $\mathrm{BC}$ & 2 & -0.16 & 4.53 & 2.18 & 6.62 & 1 \\
\hline $\mathrm{PacOc}$ & 100 & 0.40 & 12.20 & 7.95 & 4.87 & $16,22,32,33,38,47$ \\
\hline $\mathrm{AP}$ & 28 & 3.10 & 7.60 & 5.70 & 2.04 & 25,28 \\
\hline Xen & 52 & -13.90 & 9.60 & -0.45 & 11.55 & $31,35,41,44,45,46$ \\
\hline Bsmt & 19 & -15.70 & -0.49 & -9.30 & 6.96 & 45,46 \\
\hline Sed & 17 & -3.90 & -1.60 & -2.99 & 1.46 & 47 \\
\hline \multicolumn{7}{|c|}{${ }^{206} \mathrm{~Pb} /{ }^{204} \mathrm{~Pb}$} \\
\hline & $n(151)$ & Min & Max & Mean & $2 \sigma$ & References \\
\hline MVB & 53 & 18.567 & 19.580 & 18.737 & 0.289 & $16,18,19,31,37,41,47$ \\
\hline $\mathrm{SMO}$ & 10 & 18.060 & 18.860 & 18.390 & 0.540 & 29,36 \\
\hline $\mathrm{PacOc}$ & 71 & 18.049 & 19.910 & 18.736 & 0.707 & $16,33,38,39,47$ \\
\hline $\mathrm{AP}$ & 10 & 18.740 & 18.980 & 18.872 & 0.166 & 28 \\
\hline Xen & 2 & 18.804 & 19.368 & 19.086 & 0.798 & 31,41 \\
\hline Bsmt & 1 & 18.862 & 18.862 & 18.862 & 0.000 & 31 \\
\hline Sed & 4 & 18.592 & 18.935 & 18.805 & 0.303 & 47 \\
\hline \multicolumn{7}{|c|}{${ }^{207} \mathrm{~Pb} /{ }^{204} \mathrm{~Pb}$} \\
\hline MVB & 53 & 15.466 & 15.647 & 15.587 & 0.071 & $16,18,19,31,37,41,47$ \\
\hline $\mathrm{SMO}$ & 10 & 15.558 & 15.636 & 15.583 & 0.055 & 29,36 \\
\hline $\mathrm{PacOc}$ & 71 & 15.425 & 15.734 & 15.545 & 0.130 & $16,33,38,39,47$ \\
\hline $\mathrm{AP}$ & 10 & 15.540 & 15.650 & 15.602 & 0.066 & 28 \\
\hline Xen & 2 & 15.618 & 15.649 & 15.634 & 0.044 & 31,41 \\
\hline Bsmt & 1 & 15.599 & 15.599 & 15.599 & 0.000 & 31 \\
\hline Sed & 4 & 15.577 & 15.671 & 15.632 & 0.079 & 47 \\
\hline
\end{tabular}


Table 1. (Continued)

\begin{tabular}{|c|c|c|c|c|c|c|}
\hline \multicolumn{7}{|c|}{${ }^{208} \mathrm{~Pb} /{ }^{204} \mathrm{~Pb}$} \\
\hline MVB & 53 & 38.065 & 38.632 & 38.433 & 0.248 & $16,18,19,31,37,41,47$ \\
\hline SMO & 10 & 37.945 & 38.625 & 38.295 & 0.497 & 29,36 \\
\hline $\mathrm{PacOc}$ & 71 & 37.449 & 39.404 & 38.293 & 0.917 & $16,33,38,39,47$ \\
\hline $\mathrm{AP}$ & 10 & 38.340 & 38.870 & 38.590 & 0.358 & 28 \\
\hline Xen & 2 & 38.662 & 38.711 & 38.687 & 0.069 & 31,41 \\
\hline Bsmt & 1 & 38.699 & 38.699 & 38.699 & 0.000 & 31 \\
\hline Sed & 4 & 38.312 & 38.729 & 38.517 & 0.397 & 47 \\
\hline
\end{tabular}

Abbreviations are MVB = Mexican Volcanic Belt; SMO = Sierra Madre Occidental; $\mathbf{B C}=$ Baja California; PacOc $=$ Pacific Ocean; AP = Altiplano; SMS = Sierra Madre del Sur; SMOr = Sierra Madre Oriental. Total amount of analyses in parenthesis.

References: (1) Cameron and Cameron 1985; (2) Lanphere et al, 1980; (3) Verma 1984; (4) Damon et al 1981; (5) Damon et al 1983a; (6) Damon et al 1983b; (7) Moorbath et al 1978; (8) Ohmoto et al 1966; (9) McDowell et al 1978; (10) Cantagrel and Robin 1978; (11) Verma 1983a; (12) Verma and Armienta-H 1985; (13) Verma et al 1985; (14) Whitford and Bloomfield 1976; (15) Basu 1979; (16) Bohrson and Reid 1995; (17) Verma et al 1991; (18) Verma and Luhr 1993; (19) Verma and Dobson 1987; (20) Verma and Nelson 1989; (21) Gunderson et al 1986; (22) Macdougall and Lugmair 1986; (23) Besch et al 1995; (24) Saunders et al 1987; (25) Pier et al 1989; (26) Martín del Pozzo et al 1989; (27) Mahood and Halliday 1988; (28) Luhr et al 1995; (29) James and Henry 1993; (30) González-Partida et al 1989; (31) Heatherington 1988; (32) Verma 1983b; (33) Verma 1992; (34) McBirney et al 1987; (35) Nimz et al 1986; (36) Cameron et al 1986; (37) Nelson et al 1995; (38) Graham et al 1988; (39) Chen et al 1986; (40) Ferriz and Mahood 1987; (41) Verma 2000; (42) Wallace and Carmichael 1994; (43) Nixon 1988; (44) Schaaf et al 1994; (45) Ruiz et al 1988b; (46) Ruiz et al 1988a; (47) Verma 1999.
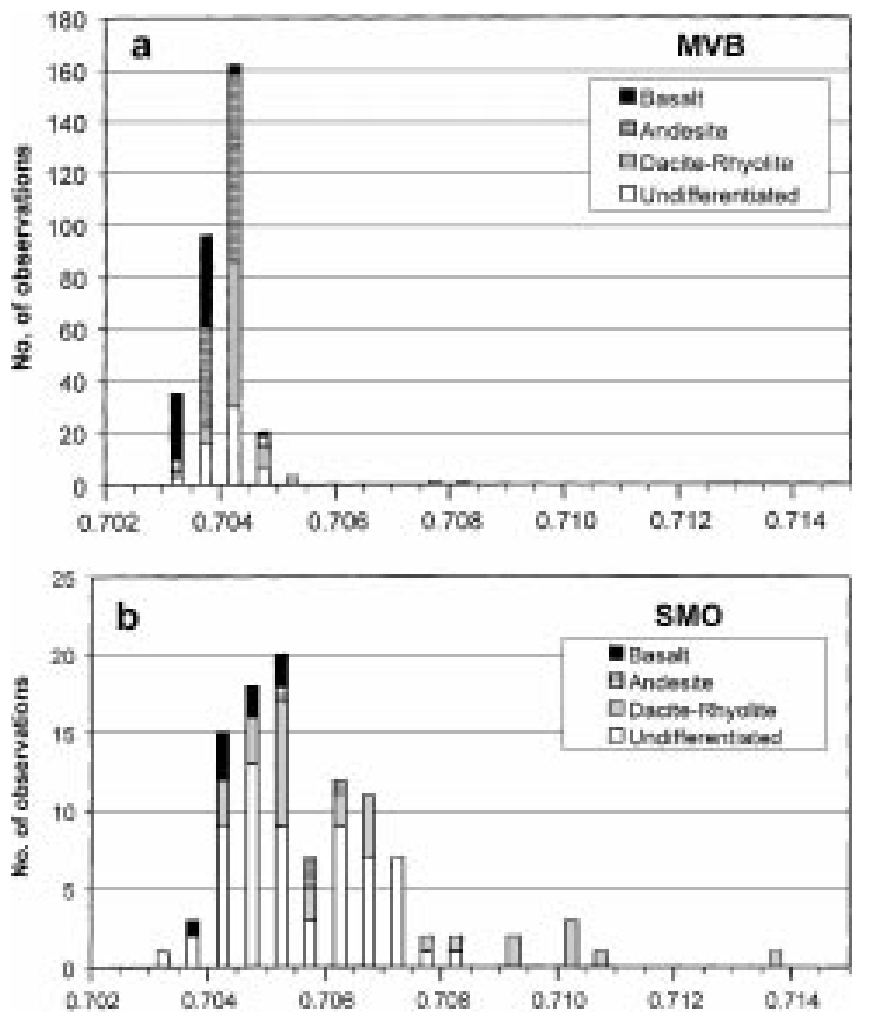

Figure 3. Sr isotopic composition of magmatic rocks from the Mexican magmatic provinces. (a) Mexican Volcanic Belt (MVB) and (b) Sierra Madre Occidental (SMO). To facilitate comparison of provinces same scale is used for ${ }^{87} \mathrm{Sr} /{ }^{86} \mathrm{Sr}(\mathrm{x}-$ axis) in all histogram plots (this figure and figures 4 and 5 ). Under the "undifferentiated" composition are included all rocks with unspecified chemical character; it may include plutonic rocks, mineral separates and generic volcanic rocks.

number of observations between 0.7030 and 0.7040 ; andesites show the highest number of observations at between 0.7035 and 0.7045 and dacites and rhyolites between 0.7040 and 0.7050 . Nd isotopic ratios range from 0.512496 to 0.513098 (arithmetic mean 0.512819 ). Lead isotopes have been analysed in fiftythree volcanic rocks from this province showing the following range: ${ }^{206} \mathrm{~Pb} /{ }^{204} \mathrm{~Pb}$ 18.567--19.580; ${ }^{207} \mathrm{~Pb} /{ }^{204} \mathrm{~Pb} \quad 15.466-15.647 ;{ }^{208} \mathrm{~Pb} /{ }^{204} \mathrm{~Pb} \quad 38.065-$ 38.632 .

\subsection{Sierra Madre Occidental (SMO)}

The SMO depicts one of the largest isotopic variations according to this compilation. Sr isotopic composition varies from 0.7033 to 0.71387 , with arithmetic mean at 0.7058 (table 1). Figure 3(b) shows the distribution of these ratios. Andesites from this province have relatively uniform ${ }^{87} \mathrm{Sr} /{ }^{86} \mathrm{Sr}$ but slightly higher values than basalts. Dacites and rhyolites, on the other hand, show a very wide distribution from between 0.7040 and $\sim 0.7140 .{ }^{143} \mathrm{Nd} /{ }^{144} \mathrm{Nd}$ values range from 0.51191 to 0.51286 (arithmetic mean: 0.51256). Ten samples have been analysed for their lead isotopic characteristics, yielding relatively homogeneous values. $\mathrm{Pb}$ isotope ratios are as follows: ${ }^{206} \mathrm{~Pb} /{ }^{204} \mathrm{~Pb} 18.060$ $18.860 ;{ }^{207} \mathrm{~Pb} /{ }^{204} \mathrm{~Pb} 15.558-15.636$; and ${ }^{208} \mathrm{~Pb} /{ }^{204} \mathrm{~Pb}$ $37.945-38.625$.

\subsection{Baja California (BC)}

Only eighteen samples from the BC magmatic province have been analysed for $\mathrm{Sr}$ isotopic composition, two for $\mathrm{Nd}$ and none for $\mathrm{Pb}$ (table 1$) .{ }^{87} \mathrm{Sr} /{ }^{86} \mathrm{Sr}$ varies from 0.70311 to 0.70629 (mean 0.70404). The distribution of these values is shown in figure 4(a). Baja Californian andesites are geochemically unusual and have been interpreted by Saunders et al (1987) as the product of the subduction of young oceanic lithosphere or subduction of a spreading centre. 

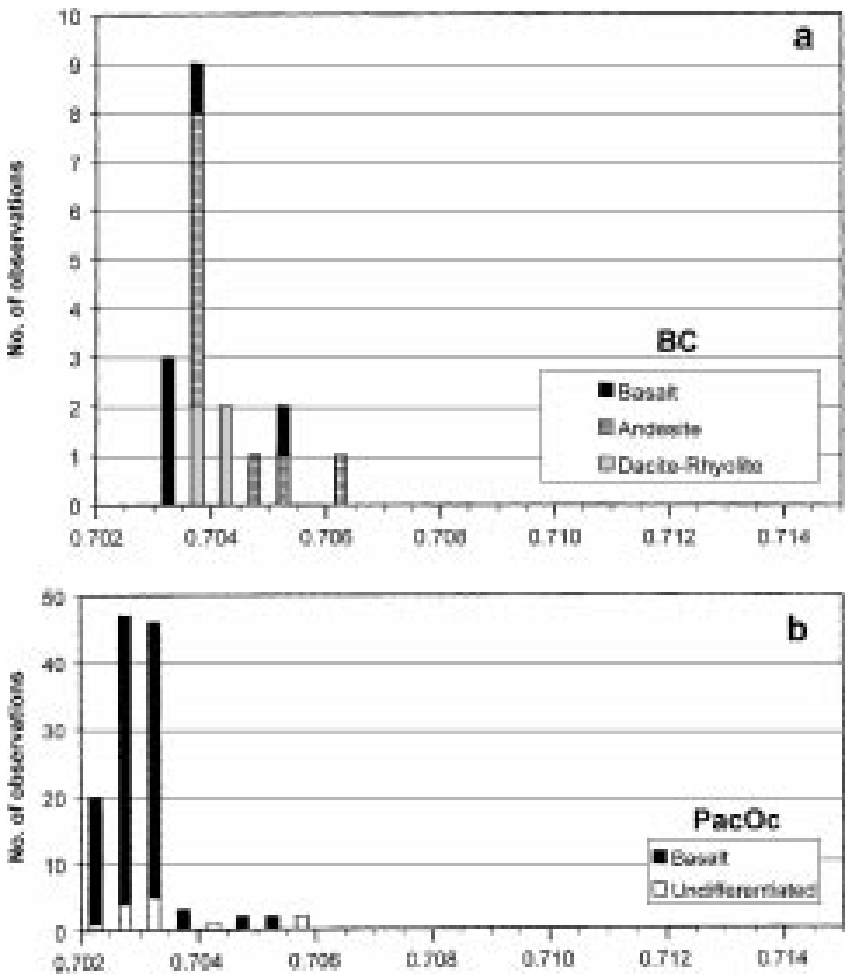

Figure 4. Sr isotopic composition of magmatic rocks from the Mexican magmatic provinces (a) Baja California (BC) and (b) Pacific Ocean (PacOc). Under the "undifferentiated" composition are all those rocks, whose chemical character was not specifically reported.

\subsection{Pacific Ocean (PacOc)}

Basalts from the East Pacific Rise, Socorro Island, seamounts and subducting Cocos Plate are included in the present compilation in the PacOc magmatic province. This kind of grouping has a geographical rather than a petrogenetic character. A total of one hundred and twenty-three samples for Sr isotopes, one hundred for $\mathrm{Nd}$ isotopes and seventy-one for $\mathrm{Pb}$ isotopes have been reported (table 1). These rocks show the most depleted $\mathrm{Sr}$ and $\mathrm{Nd}$ isotopic ratios (0.70232-0.70567 for $\mathrm{Sr}$ and 0.512631-0.513261 for $\mathrm{Nd}$ ). $\mathrm{Pb}$ isotopes for Pacific Ocean show the following range: ${ }^{206} \mathrm{~Pb} /{ }^{204} \mathrm{~Pb} \quad 18.049-19.910 ;{ }^{207} \mathrm{~Pb} /{ }^{204} \mathrm{~Pb}$ 15.425-15.734; ${ }^{208} \mathrm{~Pb} /{ }^{204} \mathrm{~Pb} \quad 37.449-39.404$, with arithmetic mean values of $18.736,15.545$, and 38.293 respectively. Figure 4(b) shows the distribution of $\mathrm{Sr}$ isotopic ratios. Most isotopic values are between 0.7020 and 0.7035. Altered basalts have higher ${ }^{87} \mathrm{Sr} /{ }^{86} \mathrm{Sr}$ as expected from interaction with seawater. In addition, two fresh rocks from Shimada seamount have high ${ }^{87} \mathrm{Sr} /{ }^{86} \mathrm{Sr}$ (figure $4(\mathrm{~b})$ ) and low $\varepsilon_{\mathrm{Nd}}$ (Graham et al 1988). The isotopic signature of PacOc samples indicates a mantle origin for these magmas. However, the data from East Pacific Rise and Socorro Island indicate some regional mantle heterogeneities. Macdougall and Lugmair (1986) include a "plume" component to explain the relatively high $\mathrm{Sr}$ and $\mathrm{Nd}$ isotopic ratios and high incompatible element concentrations in the East Pacific Rise. On the other hand, Bohrson and Reid (1995) in their study of basaltic rocks from Socorro Island conclude that ocean crustal contamination may be introduced into magmatism of Ocean Island Basalt.

\subsection{Altiplano (AP)}

In the AP magmatic region interesting rocks (hawaiite, basanite, olivine nephelinite and some alkali basalt) have been studied for their $\mathrm{Sr}, \mathrm{Nd}$ and $\mathrm{Pb}$ isotopic compositions by Pier et al (1989) and Luhr et al (1995). These authors reported twenty-eight $\mathrm{Sr}$ and $\mathrm{Nd}$ isotopic analyses, as well as ten $\mathrm{Pb}$ isotopic measurements. Sr isotopic ratios range from 0.70286 to 0.70395 . ${ }^{143} \mathrm{Nd} /{ }^{144} \mathrm{Nd}$ values vary between 0.51278 and 0.51301 . Lead isotopic ratios present a very narrow range, with calculated mean values of $18.872,15.602$, and 38.590 for ${ }^{206} \mathrm{~Pb} /{ }^{204} \mathrm{~Pb},{ }^{207} \mathrm{~Pb} /{ }^{204} \mathrm{~Pb}$, and ${ }^{208} \mathrm{~Pb} /{ }^{204} \mathrm{~Pb}$ respectively. The isotopic ratios of the $\mathrm{AP}$ rocks are within the range of those from the Pacific Ocean.

Although most of the samples from AP region show a mantle origin, crustal contamination and mixing processes have also been interpreted. Pier et al (1989) concluded from the analyses of eighteen basanite samples from San Luis Potosi, that a mixing model of three different mantle reservoirs best explains the isotopic signatures of those rocks: a depleted source, a St. Helena type component, and a third source rich in radiogenic Sr. Miocene hawaiites which crop out in the eastern margin of the Mexican Basin and Range Province present crustal contamination; up to $45 \%$ of the $\mathrm{Pb}$ in these rocks has been crustally derived (Luhr et al 1995).

\subsection{Sierra Madre del Sur (SMS) and Sierra Madre Oriental (SMOr)}

The SMS and SMOr have been sparsely studied for their isotopic characteristics. For these provinces only twenty-seven analyses for ${ }^{87} \mathrm{Sr} /{ }^{86} \mathrm{Sr}$ and none for $\mathrm{Nd}$ or $\mathrm{Pb}$ isotopes have been reported in the literature. $\mathrm{Sr}$ isotopic values for SMS range between 0.70220 and 0.70670 (arithmetic mean 0.70411). For the SMOr ${ }^{87} \mathrm{Sr} /{ }^{86} \mathrm{Sr}$ varies between 0.704 and 0.710 . The heterogeneous nature of the basement under SMS and its wide range of ages (between $32 \mathrm{Ma}$ and $246 \mathrm{Ma}$ ) suggest that the magmas in this region could not have been derived from a homogeneous source. For the SMOr scarcity of data and their low quality (considering modern standards) make it difficult to give any petrogenetic significance to these $\mathrm{Sr}$ isotopic values.

\subsection{Xenoliths, basement rocks and Cocos Plate sediments}

Present values for ${ }^{87} \mathrm{Sr} /{ }^{86} \mathrm{Sr},{ }^{143} \mathrm{Nd} /{ }^{144} \mathrm{Nd}$, ${ }^{206} \mathrm{~Pb} /{ }^{204} \mathrm{~Pb},{ }^{207} \mathrm{~Pb} /{ }^{204} \mathrm{~Pb}$, and ${ }^{208} \mathrm{~Pb} /{ }^{204} \mathrm{~Pb}$ in upper 

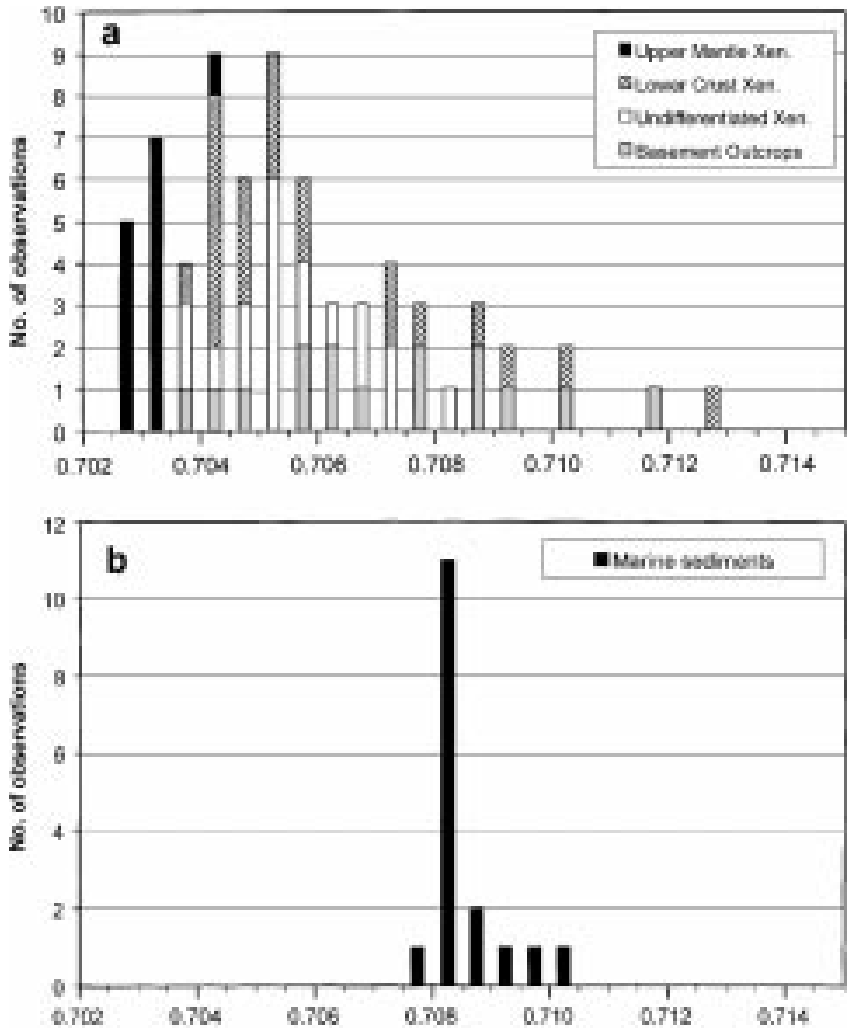

Figure 5. Sr isotopic composition of other rocks compiled in this database. (a) Xenoliths and basement outcrops, (b) Cocos Plate sediments. Four highest Sr isotopic ratios of xenolith samples (metasediments: 0.715183 and 0.727928; undifferentiated: 0.730435 and 0.731853 ) were not included in the histogram. Under the "undifferentiated xenoliths" are all those rocks, whose chemical character was not specifically reported.

mantle and lower crustal xenoliths as well as basement outcrops have been compiled in this database. The main reason for compiling measured values rather than initial ratios estimated from "model ages" is that the present isotopic compositions are more useful in petrogenetic interpretations of Mexican provinces. Statistical parameters and literature sources of these data are presented in table 1. Figure 5(a) shows the distribution of $\mathrm{Sr}$ isotopic compositions of these samples, arranged according to their provenance. Unfortunately many of the xenoliths were not properly classified and therefore are grouped as "undifferentiated" in this diagram. Upper mantle xenoliths show the lowest $\mathrm{Sr}$ isotopic ratios ranging from about 0.7025 to 0.7045 (figure 5(a)). Lower crustal xenoliths as well as basement rocks present a wide variation of ${ }^{87} \mathrm{Sr} /{ }^{86} \mathrm{Sr}$ (from about 0.7035 to 0.7130 ). ${ }^{143} \mathrm{Nd} /{ }^{144} \mathrm{Nd}$ also shows a similar variation for these xenoliths and basement rocks. For $\mathrm{Pb}$ isotopes only two measurements are available for xenoliths and one for basement rocks (table 1).

The wide variation in $\mathrm{Sr}$ and $\mathrm{Nd}$ isotopic data observed in xenoliths and basement rocks is a strong evidence of a heterogeneous lower crust in Mexico. Many low ${ }^{87} \mathrm{Sr} /{ }^{86} \mathrm{Sr}$ values (0.704-0.705; figure 5(a)) in crustal xenoliths and basement outcrops are similar to those observed in many andesitic to rhyolitic rocks from the MVB and basaltic rocks from the SMO (figure 3). This similarity in $\mathrm{Sr}$ isotopic composition makes it difficult to model the petrogenesis of volcanic rocks in subduction environment such as for the MVB and SMO.

Figure 5(b) shows the distribution of ${ }^{87} \mathrm{Sr} /{ }^{86} \mathrm{Sr}$ analysed in sediments from the Cocos Plate in the vicinity of the Middle American Trench (figure 2). For these sediments the isotopic ratios range as follows: ${ }^{87} \mathrm{Sr} /{ }^{86} \mathrm{Sr} \quad 0.707986-0.710340 ;{ }^{143} \mathrm{Nd} /{ }^{144} \mathrm{Nd}$ $0.512437-0.512556 ;{ }^{206} \mathrm{~Pb} /{ }^{204} \mathrm{~Pb} \quad 18.592-18.935$; ${ }^{207} \mathrm{~Pb} /{ }^{204} \mathrm{~Pb} \quad 15.577-15.671 ;{ }^{208} \mathrm{~Pb} /{ }^{204} \mathrm{~Pb} \quad 38.312-$ 38.729 (table 1 ).

\subsection{Some implications of Sr-Nd isotopic data}

Figure 6 presents a conventional ${ }^{87} \mathrm{Sr} /{ }^{86} \mathrm{Sr}-\varepsilon_{\mathrm{Nd}}$ diagram for basaltic rocks compiled in our database from the MVB, SMO, PacOc, and AP provinces. Most of the samples plot on or close to the "mantle array" (White 1985; Faure 1986). Altered rocks from the ocean floor are shifted to the right of the "mantle array" as a result of seawater interaction. Different contributions from the underlying crust may be the reason for the spread in isotopic compositions of basaltic rocks from these provinces. This may be the case of the MVB, with a large spread in this diagram, indicating a higher addition of crustal material and/or other magmatic processes (such as AFC).

As an attempt to examine regional variations in ${ }^{87} \mathrm{Sr} /{ }^{86} \mathrm{Sr}$ and $\varepsilon_{\mathrm{Nd}}$ the data for all samples from this compilation are plotted in figure 7 , in contrast to figure 6 where only basaltic rocks were plotted. For simplicity, the data for the MVB, SMO, PacOc, and

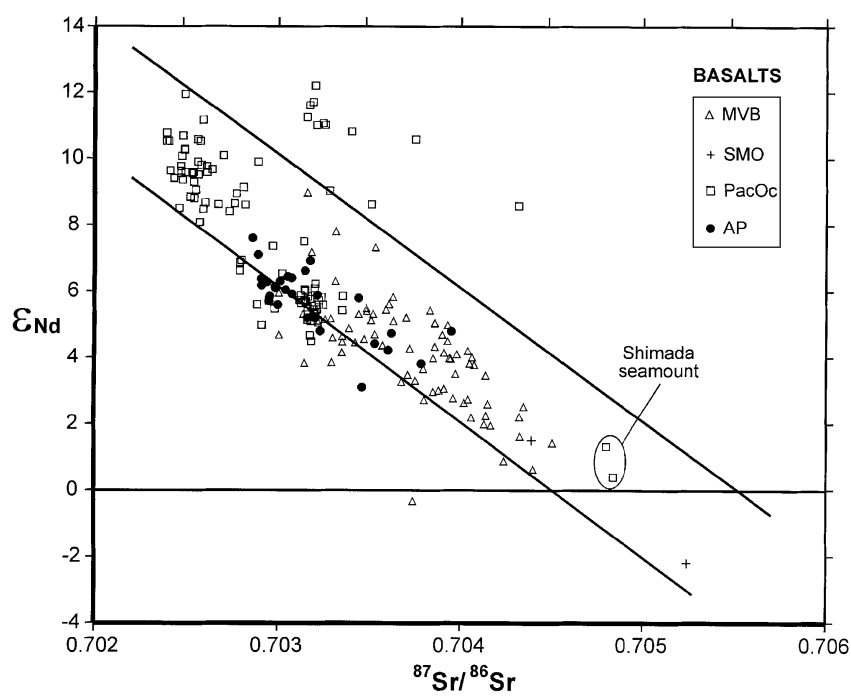

Figure 6. $\quad \varepsilon_{\text {Nd }}$ vs. ${ }^{87} \mathrm{Sr} /{ }^{86} \mathrm{Sr}$ diagram for basaltic rocks from three better-studied magmatic provinces of Mexico. Sloping lines approximate the "mantle array" (White 1985). Abbreviations are the same as in figure 1. 


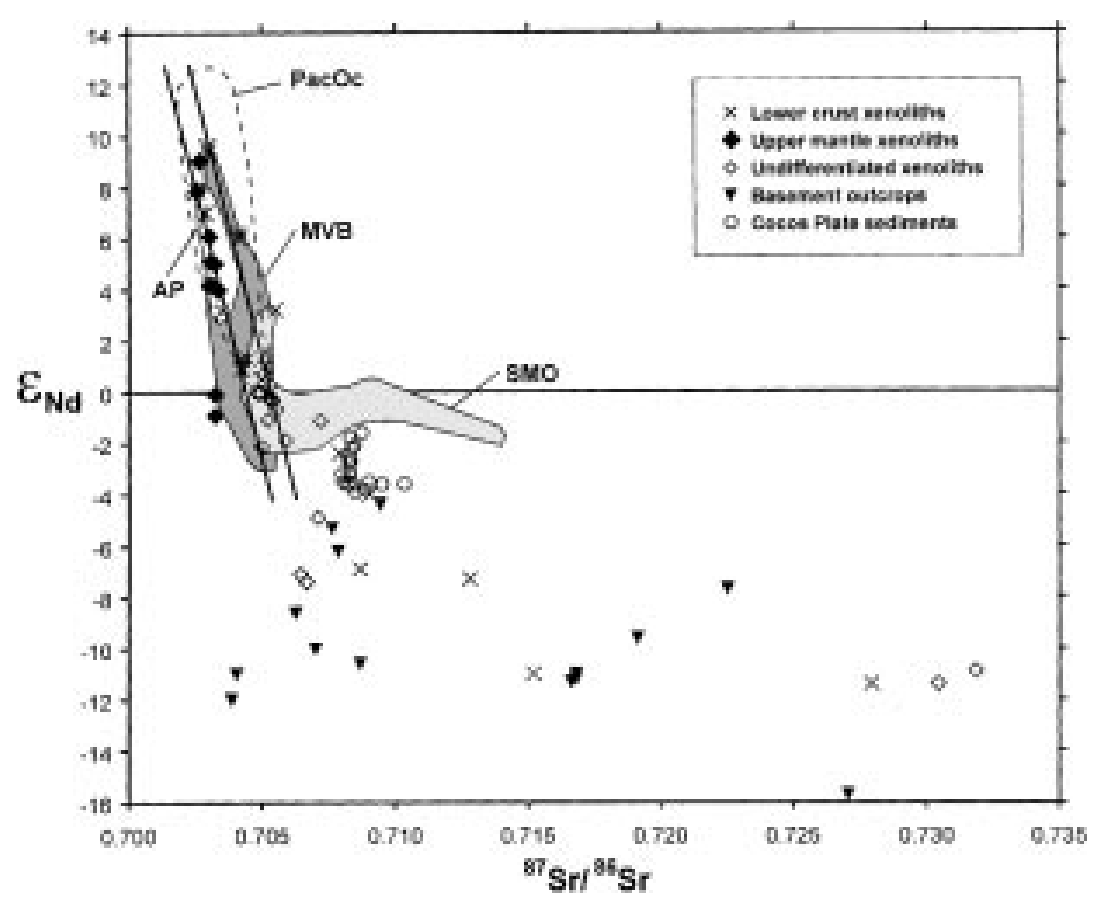

Figure 7. $\quad \varepsilon_{\mathrm{Nd}}$ vs. ${ }^{87} \mathrm{Sr} /{ }^{86} \mathrm{Sr}$ diagram for the magmatic provinces of Mexico. Sloping lines approximate the "mantle array" (White 1985). Abbreviations are the same as in figure 1. One basement sample with high $\mathrm{Sr}$ and low $\varepsilon_{\mathrm{Nd}}$ value $(0.749957$ and -13.2 respectively) is not included in this diagram. See text for explanation.

AP are shown as closed fields. Fields for the BC, SMS, and SMOr provinces are not included because of scarcity of data. Most samples from the studied magmatic provinces fall on the "mantle array" (White 1985). The SMO shows a special subhorizontal trend extending from the "mantle array" to $\mathrm{Sr}$ isotopic values up to $\sim 0.714$. At first sight, the PacOc field seems to encompass most of the AP and MVB isotopic data. This is due to two samples from Shimada seamount, which fall near the "bulk Earth" value (see figure 6) and apparently enlarge the PacOc field. Xenolith analyses show a large spread of Sr and $\mathrm{Nd}$ isotopic values. Many of them fall on the "mantle array" but extend up to very high ${ }^{87} \mathrm{Sr} /{ }^{86} \mathrm{Sr}$ and low $\varepsilon_{\text {Nd }}$ values. On the other hand, Cocos Plate sediments are relatively uniform in $\mathrm{Sr}$ and $\mathrm{Nd}$ isotopes, occupying a small area just below the SMO field.

The special trend presented by the SMO (figure 7), with relatively constant $\varepsilon_{\mathrm{Nd}}$ values has been explained by Verma (1984) and Cameron and Cameron (1985) as the product of a two-component mixing model. According to them, mantle derived magmas (composition similar to the basalts represented by crosses in figure 6) mix with different proportions of continental crust. This mixing process is supposed to be accompanied by extensive fractional crystallisation at shallow levels before eruption, thus producing large volumes of differentiated magmas in this province.

${ }^{87} \mathrm{Sr} /{ }^{86} \mathrm{Sr}$ and ${ }^{206} \mathrm{~Pb} /{ }^{204} \mathrm{~Pb}$ for all samples are presented in figure 8 . The MVB samples fall on the right side of the Prevalent Mantle reservoir (PREMA, Zindler and Hart 1986). Low ${ }^{87} \mathrm{Sr} /{ }^{86} \mathrm{Sr}$ and high

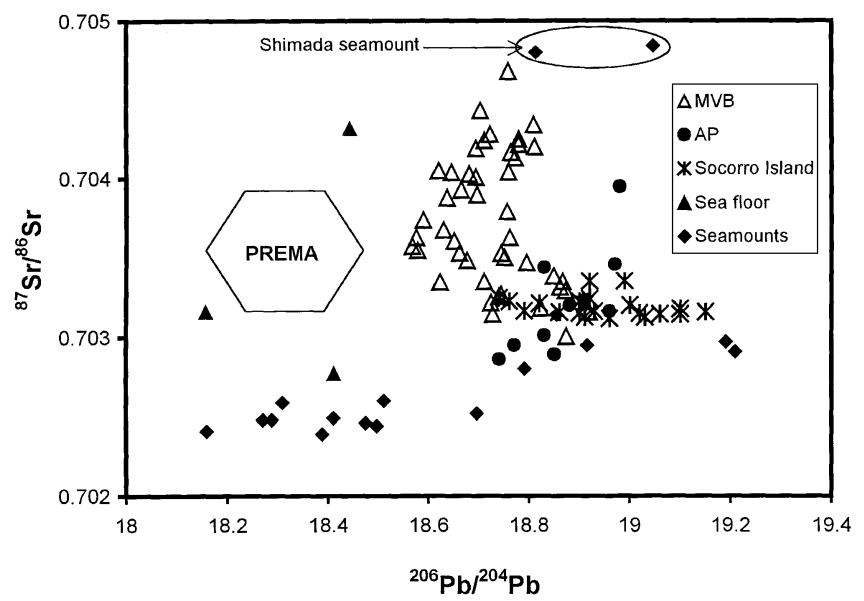

Figure 8. ${ }^{87} \mathrm{Sr} /{ }^{86} \mathrm{Sr}$ vs. ${ }^{206} \mathrm{~Pb} /{ }^{204} \mathrm{~Pb}$ diagram for magmatic rocks from Mexican provinces. PREMA: Prevalent Mantle reservoir (Zindler and Hart 1986).

${ }^{206} \mathrm{~Pb} /{ }^{204} \mathrm{~Pb}$ samples from the MVB overlap with the field occupied by the AP and Socorro Island rocks. Sr isotopic values from Socorro Island are much more homogeneous than those of AP samples. Bohrson and Reid (1995) suggested oceanic crust as a contamination source of Socorro Island basalt. Large variation in $\mathrm{Pb}$ isotopic data from Socorro Island indicates a component with a high ${ }^{206} \mathrm{~Pb} /{ }^{204} \mathrm{~Pb}$. Seamounts from the Pacific Ocean show the largest spread in $\mathrm{Pb}$ isotopic ratios, as compared to ${ }^{87} \mathrm{Sr} /{ }^{86} \mathrm{Sr}$. Two samples from Shimada seamount plot on the top of the diagram. Their origin has been related to a young intraplate hotspot (Graham et al 1988). 
There is no doubt that more data are needed, especially for $\mathrm{Pb}$ and $\mathrm{Nd}$ isotopes (see table 1), in order to have a better understanding of the origin of Mexican magmatic provinces and for the construction of more reliable petrologic models. Other major and petrogenetically important trace elements should also be compiled to better understand the origin and evolution of Mexican magmatic provinces.

\section{Conclusions}

Most magmatic rocks lay on the "mantle array" in ${ }^{87} \mathrm{Sr} /{ }^{86} \mathrm{Sr}-{ }^{143} \mathrm{Nd} /{ }^{144} \mathrm{Nd}$ diagram, suggesting the mantle as an important magma source for all Mexican magmatic provinces. The source is however not uniform. Different magmatic processes, such as crustal contamination, magma mixing and AFC, also contribute to the diversity of magmas in these provinces. This may be the case of the MVB, with a large spread in $\mathrm{Sr}$ and $\mathrm{Nd}$ isotopic ratios. The presence of lower crustal xenoliths with similar isotopic compositions to the "mantle array" makes it difficult to adopt the upper mantle as a unique source. The SMO seems to have been formed by a mixing process between mantle derived magmas and continental crust. More isotopic data, particularly $\mathrm{Nd}$ and $\mathrm{Pb}$ isotopes, are required for a better understanding of the origin and evolution of Mexican magmatic provinces.

\section{Acknowledgements}

This work was supported by the UNAM (DGAPA IN100596 and IN-106199) and CONACYT (0196P-T) projects.

\section{References}

Aguilar-Y-Vargas V H and Verma S P 1987 Composición química (elementos mayores) de los magmas en el Cinturón Volcánico Mexicano; Geofís. Int. 26 273-290.

Atwater T 1989 Plate tectonic history of the northeast Pacific and western North America. Chapter 4, In: The Eastern Pacific Ocean and Hawaii. The Geology of North America, Boulder, Colorado, (eds) E L Winterer, D M Hussong and R W Decker, The Geological Society of America 21-72.

Basu A R 1979 Geochemistry of ultramafic xenolith from San Quintin, Baja California, (eds) F R Boyd and H O A Meyer, In: The mantle sample: Inclusions in kimberlites and other volcanics. (Washington, DC: AGU) 2: 391-423

Besch T, Verma S P, Kramm U, Negendank J F W, Tobschall H J, and Emmermann R 1995 Assimilation of sialic crustal material by volcanics of the easternmost extension of the Trans-Mexican Volcanic Belt Evidence from $\mathrm{Sr}$ and $\mathrm{Nd}$ isotopes; Geofis. Int. 34 263-281

Bohrson W A and Reid M R 1995 Petrogenesis of alkaline basalts from Socorro Island, Mexico: trace element evidence for contamination of ocean island basalt in the shallow acean crust; J. Geophys. Res. 100 24555-24576

Cameron K L and Cameron M 1985 Rare earth element, ${ }^{87} \mathrm{Sr} /{ }^{86} \mathrm{Sr}$, and ${ }^{143} \mathrm{Nd} /{ }^{144} \mathrm{Nd}$ compositions of Cenozoic oro- genic dacites from Baja California, northwestern Mexico, and adjacent west Texas: evidence for the predominance of a subcrustal component; Contrib. Mineral. Petrol. 91 1-11

Cameron K L, Cameron M and Barreiro B 1986 Origin of voluminous mid-tertiary ignimbrites of the batopilas region, Chihuahua: implications for the formation of continental crust beneath the Sierra Madre Occidental; Geofís. Int. 25 39-59

Campa M F and Coney P J 1983 Tectono-stratigraphic terranes and mineral resource distributions of Mexico; Can. J. Earth Sci. 20 1040-1051

Cantagrel J-M and Robin C 1978 Géochemie isotopique du strontium dans quelques séries types du volcanisme de l'Est mexicain; Bull. Soc. Geol. France 20 935-939

Cantagrel J M and Robin C 1979 K-Ar dating on Eastern Mexican volcanic rocks-relations between the andesitic and the alkaline provinces; J. Volcanol. Geotherm. Res. 5 99-114

Carfantan J C 1986 Du systeme cordilletain Nor-Americain ai domaine Caraibe. Thése Doctorat d'Etat, Université de Savoie, 558 pp.

Cebull S E and Shurbet D H 1987 Mexican Volcanic Belt: an intraplate transform?; Geofís. Int. 26 1-13

Chen J H, Wasserburg G J, von Damm K L and Edmond J M 1986 The U-Th-Pb systematics in hot springs on the East Pacific Rise at $21^{\circ} \mathrm{N}$ and Guaymas Basin; Geochim. Cosmochim. Acta 50 2467-2479

De Cserna Z 1989 An outline of the geology of Mexico. (eds) A W Bally and A R Palmer, In: The Geology of North America An overview, The Geology of North America, Boulder, Colorado (Geological Society of America), 233-264

Demant A 1978 Características del eje neovolcánico transmexicano y sus problemas de interpretación; Rev. Inst. Geol. UNAM 2 172-187

Demant A 1981 L'Axe Néovolcanique Mexicain, étude volcanologique et pétrographique-signification géodynamique. Thése Doctorat d'Etat, Aix-Marseille University, 259 pp

Demant A and Robin C 1975 Las fases del vulcanismo en México: una síntesis en relación con la evolución geodinámica desde el Cretácico; Rev. Inst. Geol. UNAM, 1 70-82

Damon P E, Shafiqullah M and Clark K F 1981 Age trends of igneous activity in relation to metallogenesis in the Southern Cordillera. (eds) W R Dickinson and W D Payne, In: Relations of Tectonics to Ore deposits in the Southern Cordillera, XIV, (Tucson, Arizona: Arizona Geological Society Digest) 137-154

Damon P E, Shafiqullah M and Clark K F 1983a Geochronology of the porphyry copper deposits and related mineralization of Mexico; Can. J. Earth Sci. 20 1052-1071

Damon P E, Shafiqullah M, Roldán Q J and Jauqes, C J 1983b El batolito Laramide (90-40 m.a.) de Sonora. Mem. XV Convención Nac. Asoc. Ing. Minas, Metalurg. Geol. México; Guadalajara, Jal. 63-95

Delgado G H 1994 Comparative studies on the Tectonics and Volcanism of Circum-Pacific Arcs; Geofís. Int. 33 5-19

DePaolo D J and Wasserburg G J 1976 Nd isotopic variations and petrogenetic models; Geophys. Res. Lett. 3 249-252

Faure G 1986 Principles of isotope geology. (New York: Wiley) $653 \mathrm{pp}$.

Ferrari L, Garduño V H, Pascuaré G and Tibaldi A 1994 Volcanic and tectonic evolution of central Mexico: Oligocene to present; Geofis. Int. 33-1 91-105

Ferriz H and Mahood G A 1987 Strong compositional zonation in a silicic magmatic system: Los Humeros, Mexican Neovolcanic Belt; J. Petrol. 28 171-209

Gastil R G and Jensky W 1973 Evidence for strike-slip displacement beneath the Trans-Mexican Volcanic Belt. (eds) R I Kovach and A Nur, In: Proc. Conf. Tectonic Problems of the San Andreas Fault System (Stanford Univ. Publ., Geol. Sci.) 13, 171-180. 
Gastil G, Allison E C and Phillips R P 1971 Reconocimiento geológico del Edo. de Baja California; Mapa 1:250,000.

González-Partida E, Casar-Aldrete I, Morales-Puente P and Nieto-Obregón J 1989 Fechas de Rb-Sr (Maastrichtiano y Oligoceno) de rocas volcánicas e intrusivas de la región de Zihuatanejo, Sierra Madre del Sur de México; Rev. Inst. Geol. UNAM, 8 248-249.

Graham D W, Zindler A, Kurz M D, Jenkins W J, Batiza R and Staudigel H $1988 \mathrm{He}, \mathrm{Pb}$, Sr and Nd isotope constraints on magma genesis and mantle heterogeneity beneath young Pacific seamounts; Contrib. Mineral. Petrol. 99 446-463

Gunderson R, Cameron K and Cameron M 1986 Mid-Cenozoic high-K calc-alkalic and alkalic volcanism in eastern Chihuahua, Mexico: geology and geochemistry of the BenavidesPozos area; Geol. Soc. Am. Bull. 97 737-753

Gunn B M and Mooser F 1971 Geochemistry of the volcanics of Central Mexico; Bull. Volcanol. 34 577-616

Heatherington A L 1988 Isotopic systematics of volcanics from south-central Rio Grande Rift and the western Mexican Volcanic Belt: Implications for magmatic and tectonic evolution of Cenozoic extensional regimes in Western North America. (Ph.D. Thesis, Washington University, St. Louis. MO), 207 pp.

Herrmann U R, Nelson B K and Ratschbacher L 1994 The origin of a terrane: $\mathrm{U} / \mathrm{Pb}$ zircon geochronology and tectonic evolution of the Xolapa complex (southern Mexico); Tectonics 13 455-474

James E W and Henry C D 1993 Southeastern extent of the North American craton in Texas and northern Chihuahua as revealed by $\mathrm{Pb}$ isotopes; Geol. Soc. Am. Bull. 105 116-126

Lanphere M A, Cameron K L and Cameron M 1980 Sr isotopic geochemistry of voluminous rhyolitic ignimbrites and related rocks, Batopilas area, western Mexico; Nature 286 594-596

Lugmair G W and Marti K 1978 Lunar initial ${ }^{143} \mathrm{Nd} /{ }^{144} \mathrm{Nd}$ : differential evolution of the lunar crust and mantle; Earth Planet. Sci. Lett. 39 349-357

Luhr F J, Pier G J, Aranda-G and Podosek F 1995 Crustal contamination in early Basin-and-Range hawaiites of the Los Encinos Volcanic Field, central Mexico; Contrib. Mineral. Petrol. 118 321-339

Luhr J F 1997 Extensional tectonics and the diverse primitive volcanic rocks in the western mexican volcanic belt; Can. Mineral. 35 473-500

Lyle M and Ness G E 1991 The opening of the southern Gulf of California. (eds) J P Dauphin and B R T Simoneit In: The Gulf and Peninsular Province of the Californias. (AAPG Memoir 47, Tulsa, Oklahoma) 403-423

Macdougall J D and Lugmair G W 1986 Sr and Nd isotopes in basalts from the East Pacific Rise: significance for mantle heterogeneity; Earth Planet. Sci. Lett. 77 273-284

Mahood G A and Halliday A N 1988 Generation of high-silica rhyolite: a $\mathrm{Nd}, \mathrm{Sr}$, and $\mathrm{O}$ isotopic study of Sierra La Primavera, Mexican Neovolcanic Belt; Contrib. Mineral. Petrol. 100 183-191

Márquez A, Verma S P, Anguita F, Brandle J L and Oyarzun R 1999 Tectonics and volcanism of Sierra Chichinautzin: Extension at the front of the central Trans-Mexican Volcanic Belt; J. Volcanol. Geotherm. Res. 93 125-150

Martín del Pozzo A L, Morales Puente P, Casar Aldrete I and Urrutia Fucugauchi J 1989 Strontium isotopic and geochemical data from the Chichinautzin monogenetic volcanic field, basin of Mexico crustal structure, and composition of the magmatic arc; Comunicaciones Técnicas Instituto de Geofísica UNAM, Serie Investigación 105 1-11

McBirney A R, Taylor H P and Armstrong R L 1987 Paricutin re-examined: a classical example of crustal assimilation in calc-alkaline magma; Contrib. Mineral. Petrol. 95 4-20

McDowell F W, Duex T W, Henry C D and Long L E 1978 Age and strontium isotope chemistry of the Sierra Mader
Occidental volcanic province, western Mexico; U.S.G.S. Open-file Report 78-701 289-291

Molnar P and Sykes L R 1969 Tectonics of the Caribbean and Middle American region from focal mechanism and seismicity; Geol. Soc. Am. Bull. 80 1639-1684

Molnar P and Stock J 1987 Relative motions of hotspots in the Pacific, Atlantic and Indian oceans since late Cretaceous time; Nature 327 587-591

Moorbath S, Thorpe R S and Gibson I L 1978 Strontium isotope evidence for petrogenesis of Mexican andesites; Nature 271 437-438.

Mooser F 1972 The Mexican Volcanic Belt-structure and tectonics; Geofis. Int. 12 55-70

Mooser F and Maldonado K M 1961 Penecontemporaneous tectonics along the Mexican Pacific coast; Geofís. Int. 1 1-20

Morán Zenteno D J, Alba-Aldave L A, Martínez-Serrano R, Reyes-Salas M, Corona-Esquivel R and Angeles-García S 1998 Stratigraphy, geochemistry and tectonic significance of the Tertiary volcanic sequences of the Taxco-Quetzalapa region; Rev. Mex. Cienc. Geol. (in press)

Nelson S A, Gonzalez-Caver E and Kyser T K 1995 Constraints on the origin of alkaline and calc-alkaline magmas from the Tuxtla volcanic field, Veracruz, Mexico. Contrib. Mineral. Petrol. 122 191-211

Nimz G J, Cameron K L, Cameron M and Morris S L 1986 The petrology of the lower crust and upper mantle beneath southeastern Chihuahua, Mexico: A progress report; Geofis. Int. 25 85-116

Nixon G T 1982 The relationship between Quaternary volcanism in central Mexico and the seismicity and structure of subducted ocean lithosphere; Geol. Soc. Am. Bull. 93 514-523

Nixon G T 1988 Petrology of the younger andesites and dacites of Iztaccíhuatl Volcano, Mexico: II. Chemical stratigraphy, magma mixing, and the composition of basaltic magma influx; J. Petrol. 29 265-303

Nixon G T, Demant A, Amstrong R L and Harakal E 1987 K$\mathrm{Ar}$ and geologic data bearing on the age and evolution of the Trans-Mexican Volcanic Belt; Geofís. Int. 26 109-158

Ohmoto H, Hart S R and Holland H D 1966 Studies in the provincia area, Mexico, II K-Ar and Rb-Sr ages of intrusive rocks and hydrothermal minerals; Econ. Geol. 61 1205-1213

Ortega-Gutiérrez F 1981 Metamorphic belts of southern Mexico and their tectonic significance; Geofís. Int. 20 177-202

Ortega-Gutiérrez F 1983 Tectonostratigraphic analysis and significance of the Paleozoic Acatlán Complex of Southern Mexico: First Circum-Pacific and Circum-Atlantic Conference Terrane Geology of Southern Mexico; Guidebook of field trip B, Instituto de Geologia, UNAM 54-60.

Pardo M and Suárez G 1995 Shape of the subducted Rivera and Cocos plates in southern Mexico: seismic and tectonic implications; J. Geophys. Res. 100 12357-12373

Pasquaré G, Vessoli L and Zanchi A 1987 Morphological and structural model of Mexican Volcanic Belt; Geofís. Int. 26 159-176

Pier J G, Podosek F A, Luhr J F, Brannon J C and ArandaGomez J J 1989 Spinel-lherzolite-bearing Quaternary volcanic centers in San Luis Potosí, Mexico. 2. Sr and Nd isotopic systematics; J. Geophys. Res. 94 7941-7951

Robin C 1981 Relations volcanologie-magmatologie-géodynamique: application au passage entre volcanismes alcalin et andésitique dans le sud Mexicain. Thése Doctorat d'Etat, Clermont-Ferrand University, $503 \mathrm{pp}$.

Rollinson H R 1993 Using Geochemical Data: Evaluation, Presentation, Interpretation. (Longman Scientific Technical, Esex, England), 344 pp.

Ruiz J, Patchett P J and Arculus R J 1988a Nd-Sr isotope composition of lower crustal xenoliths - evidence for the origin of mid-Tertiary felsic volcanics in Mexico; Contrib. Mineral. Petrol. 99 36-43 
Ruiz J, Patchett P J and Ortega-Gutierrez F 1988b Proterozoic and Phanerozoic basement terranes of Mexico from Nd isotopic studies; Geol. Soc. Am. Bull. 100 274-281

Salters V J M 1996 The generation of mid-ocean ridge basalts from the Hf and Nd isotope perspective; Earth Planet. Sci. Lett. 141 109-123

Saunders A D, Rogers G, Marriner G F, Terrell D J and Verma S P 1987 Geochemistry of Cenozoic volcanic rocks, Baja California, Mexico: implications for the petrogenesis of postsubduction magmas; J. Volcanol. Geotherm. Res. 32 223245

Schaaf P, Heinrich W and Besch T 1994 Composition and SmNd isotopic data of the lower crust beneath San Luis Potosí, central Mexico: evidence from a granulite-facies xenolith suite; Chem. Geol. 118 63-84

Schaaf P, Morán Zenteno D, Hernández-Bernal M S, SolísPichardo G, Tolson G and Köhler H 1995 Paleogene continental margin truncation in southwestern Mexico: Geochronological evidence; Tectonics 14-5 1339-1350

Shurbet D H and Cebull S E 1984 Tectonic interpretation of the Trans-Mexicano Volcanic Belt; Tectonophysics 101 159-165

Steiger R H and Jäger E 1977 Subcommission on geochronology: convention on the use of decay constants in geo- and cosmochronology; Earth Planet. Sci. Lett. 36 359-362

Tera F, Brown L, Morris J, Sacks I S, Klein J and Middleton R 1986 Sediment incorporation in island-arc magmas: inferences from ${ }^{10} \mathrm{Be}$; Geochim. Cosmochim. Acta 50 535-550

Urrutia J and Böhnel H 1987 Tectonic interpretation of the Trans-Mexican Volcanic Belt- discussion; Tectonophysics 138 319-323

Venegas S S, Herrera J and Macial F 1985 Algunas caracteristicas de la Faja Volcanica Mexicana y sus recursos geotermivos; Geofís. Int. 24-1 47-83

Verma S P 1983a Magma genesis and chamber processes at Los Humeros caldera, Mexico-Nd and Sr isotope data; Nature $30152-55$

Verma S P 1983b Strontium and neodymium isotope geochemistry of igneous rocks from the North East Pacific and Gulf of California; Isot. Geosci. 1 339-356

Verma S P 1984 Sr and Nd isotopic evidence for petrogenesis of mid-tertiary felsic volcanism in the mineral district of Zacatecas, Zac. (Sierra Madre Occidental), Mexico; Isot. Geosci. 2 37-53

Verma S P 1987 Mexican Volcanic Belt: present state of knowledge and unsolved problems; Geofis. Int. 26 309-340

Verma S P 1992 Seawater alteration effects on REE, K, Rb, Cs, $\mathrm{Sr}, \mathrm{U}, \mathrm{Th}, \mathrm{Pb}$, and $\mathrm{Sr}-\mathrm{Nd}-\mathrm{Pb}$ isotope systematics of MidOcean Ridge Basalt; Geochem. J. 26 159-177
Verma S P 1994 Geochemical and isotopic constraints on the origin of mafic volcanism in central Mexico; Mineral. Mag. 58A 938-939

Verma S P 1999 Geochemistry of subducting Cocos plate and the origin of subduction-unrelated mafic volcanism at the volcanic front of the central Mexican Volcanic Belt. Geol. Soc. Am. Spec. Paper on Cenozoic Tectonics and Volcanism of Mexico 334, chapter 13 (in press)

Verma S P 2000 Geochemical evidence for a lithospheric source for magmas from Los Humeros Caldera, Puebla, Mexico; Chem. Geol. 164 35-60

Verma S P and Aguilar-Y-Vargas V H 1988 Bulk chemical composition of magmas in the Mexican Volcanic Belt (Mexico) and inapplicability of generalized arc-models; Chem. Erde 48 203-221

Verma S P and Armienta-H M A $1985{ }^{87} \mathrm{Sr} /{ }^{86} \mathrm{Sr}$, alkali and alkaline earth element geochemistry of Chichinautzin Sierra, Mexico; Geofís. Int. 24 665-678

Verma S P and Dobson P F 1987 Sr, Nd, O and Pb isotopic evidence for complex petrogenetic evolution of silicic lavas in the Los Azufres volcanic field, Michoacán, Mexico: EOS Trans. Am. Geophys. Un. 681520 (abstract)

Verma S P and Luhr J F 1993 Sr-Nd-Pb isotope and trace element geochemistry of calc-alkaline andesites from Volcán Colima, Mexico; Geofís. Int. 32 617-631

Verma S P and Nelson S A 1989 Isotopic and trace element constraints on the origin and evolution of alkaline and calcalkaline magmas in the northwestern Mexican Volcanic Belt; J. Geophys. Res. 94 4531-4544

Verma S P and Verma M P 1986 A compilation of Sr and Nd isotope data on Mexico; J. Geol. Soc. India 27 130-143

Verma S P, Lopez-Martinez M and Terrell D J 1985 Geochemistry of tertiary igneous rocks from Arandas-Atotonilco area, northeast Jalisco, Mexico; Geofís. Int. 24-1 31-45

Verma S P, Carrasco-Núñez G and Milán M 1991 Geology and geochemistry of Amealco caldera, Qro., Mexico; J. Volcanol. Geotherm. Res. 47 105-127

Wallace P J and Carmichael I S E 1994 Petrology of Volcán Tequila, Jalisco, Mexico: Disequilibrium phenocryst assemblages and evolution of the subvolcanic magma system; Contrib. Mineral. Petrol. 117 345-361

White W M 1985 Sources of oceanic basalts: radiogenic isotopic evidence; Geology 13 115-118

Whitford D J and Bloomfield K 1976 Geochemistry of Late Cenozoic volcanic rocks from the Nevado de Toluca area, Mexico; Carnegie Inst. Wash. Yearb. 75 207-213

Zindler A and Hart S 1986 Chemical geodynamics; Annu. Rev. Earth Planet. Sci. 14 493-571 